\title{
Improving Students' Writing Skill through the School Online Newspaper at a Public University in Vietnam
}

\author{
Lê Thị Thu Trang*, Lê Thị Khánh Linh \\ School of Foreign Languages, Thai Nguyen University \\ Corresponding author: Lê Thị Thu Trang, E-mail: lethutrang10.sfl@tnu.edu.vn
}

\section{ARTICLE INFO}

Article history

Received: January 31, 2018

Accepted: April 22, 2018

Published: April 30, 2018

Volume: 6 Issue: 2

Conflicts of interest: None

Funding: None

\begin{abstract}
Writing is a crucial skill for students, particularly for those at tertiary level, yet it is a fact that many find writing challenging to master. A number of methods and strategies, therefore, have been employed in an attempt to develop students' writing skill, and a student-run school newspaper is one of them. This paper aims at reporting whether the school newspaper The SFLook results in its members' improved writing and how the students self-evaluate the impact of the project. First, the students' $(n=20)$ pre-test and post-test before and after a twelve-week action were examined to assess their writing performance. Besides, a questionnaire was delivered to investigate their attitudes towards different aspects during the time working for the newspaper. The findings indicate that the school newspaper has reinforced its members' writing skill and their motivations for writing are bound to external factors. The research results would suggest further applications of student - run newspapers in various educational contexts.
\end{abstract}

Key words: Writing; Student-run School Newspaper; Attitudes

\section{INTRODUCTION}

Hedge (2005) describes that writing is more than producing accurate and complete sentences and phrases. She also states that writing is about guiding students to produce whole pieces of communication, to link and develop information, ideas, or arguments for particular reader or a group of readers. Writing plays a significant role in language learning because it allows learners to achieve such sub-skills as independence, comprehensibility, fluency and creativity. However, as a complex cognitive activity, writing for English as a Foreign Language (EFL) learners is believed to be more difficult to teach than the other language skills namely listening, speaking and reading since it requires learners to demonstrate control of variables simultaneously (Nunan, 1989; Mazdayasna \& Tahririan, 2001). Obviously, although EFL learners make considerable efforts to write a composition, the results are often unsatisfactory due to factors like writing anxiety and writer's block. In fact, many students' compositions are found incoherent and unpersuasive in communicating ideas.

Regarding numerous methods to enhance students' writing skill, giving students more freedom to write and empowering them are worth considering. One instance for this is the model of student-run newspaper, which is created by and for students. The use of the student-run newspaper is expected to exercise positive impact on students' writing performance and contribute to driving back their negative feelings when writing. While this model houses notable applicability, it has not received proper attention. Relatively little research has been conducted to examine the effect of the school newspaper on students' language skills, especially writing. Therefore, this paper aims to assess the impact of a student-run newspaper, at a public university in Vietnam, The SFLook, on its members' writing skill. It is motivated by two research questions:

1. To what extent does the student-run newspaper The SFLook affect the members' writing performance?

2. What are the members' attitudes towards the school online newspaper?

Once these questions are fully addressed, the paper is hoped to provide an insight into the implementation of the school newspaper in teaching and learning writing at tertiary institutions.

\section{LITERATURE REVIEW}

\section{EFL Writing Teaching and Learning in Vietnam}

Teaching writing among Vietnamese EFL learners has been of interest to researchers and educators for years. Like other ASEAN countries, the teaching of English writing was characterized by the focus on grammar and sentence structure and the teaching approach seemed to be mostly product-based (Pham, 2000). Currently, process genre-based and communicative approaches have been integrated in writing classes and they prove their own effectiveness.

Many have investigated challenges to Vietnamese learners of English when it comes to writing. For example, 
they have to tackle the lack of vocabularies and ideas, limitations on grammatical knowledge, and less confidence (Nguyen et al. 2011). Another problem is related to motivation as most students find writing difficult and unrewarding. Vietnamese EFL learners are motivated mainly by the "teacher's initiative" and the "students" will to succeed" in examinations, not by their intrinsic needs (Ellis, 1996). Le (2000) also stresses that the pressure to pass exams has resulted in the fact that Vietnamese learners are bound to extrinsic factors.

A number of methods and strategies have been implemented to help students sharpen their writing skill. Nguyen et al.(2011) investigated the effect of numerous activities in EFL writing classes like free writing, pyramid sharing and deciding, group drafting, and peer support, and concluded that they contribute to the students' significant improvement in their writing performance. An action research conducted by Nguyen (2016) indicates that the implementation of critical thinking has positive impacts on students' attitudes to writing and their writing performance. A point to consider is that technology adoption has gained its popularity in classroom practice (Dang, 2011).

\section{School Newspaper}

According to Oxforddictionaries.com, an online newspaper is a regularly updated publication containing news articles and other content relating to current events; (sometimes) specifically the digital version of a print newspaper. In his paper, Student newspapers at Public Colleges and Universities: Lessons from the United States, Hapney and Russo (2013) state that student newspapers play four important roles in a university campus. First, life on campuses is chronicled when readers are informed various kinds of events ranging from academic to extra-curricular events. Second, the press acts as a forum in which student readers are allowed to express personal opinions. Third, several problems are also covered like violation and crime since the newspaper is considered as a watchdog. Finally, this is a training opportunity for students to work as a journalist after graduating from colleges. In contrast, Krajka (2000) mentions a list of advantages of e-papers retaining the possibility to retrieve older issues quickly and without additional expenses, the possibility to change to another paper if the one chosen is inappropriate for some reasons, the possibility to bookmark or subscribe to the site (still for free), and the possibility to print it out and use it as normal paper or save it to disk, open it in a word processing program and edit for one's own purposes (providing there is no breach of copyright laws).

On the other hand, Krajka (2000) also points out several disadvantages or the weak sides of online newspaper. Firstly, many people find it hard to read words on a computer screen since its flickers and images cause ones' eyes to tire. Besides, banners as well as advertisements often appear and these make readers distracted. Thirdly, without the control and supervision of lecturers, students might not be interested in the press and cease to read. Hence, student motivation and teacher role are of great importance when maintaining a publication.

\section{Attitude Measurements}

Attitude is generally defined as a state of mind, which is influenced by feelings, belief, and experience of the world (Gibb, 1999). Ajzen (2005) believes that attitude, like personality trait, is a hypothetical construct that is inaccessible to direct observation and must be inferred from measurable responses. These responses must reflect positive or negative evaluations of the attitude object. He states that an attitude is a disposition to respond favorably or unfavorably to the object, person, institution, or event.

Meanwhile, Wenden (1991) sees that attitudes include three components: cognitive, affective, and behavior intention component. First, attitude tends to have a cognitive component which could involve beliefs or perceptions about the objects or situations related to the attitude. Second, the affective component of attitude includes feeling about and evaluation of the subject. Third, behavioural component is certain attitudes that tend to prompt learners to adopt particular learning behavior.

As Ajzen (2005) notes, direct methods in attitude measurement consist of questionnaires and interviews. The main idea in these techniques is to ask subjects directly about their language attitudes. Attitudes, according to Kalaja (1999), can be measured towards any language or its varieties, for example, subjects can be asked about their attitudes towards British English and American English. Moreover, research can be carried out, for instance, about people's attitudes towards Finnish and Swedish, or regional and social dialects of British English. Interviews and questionnaires can, as Oskamp and Shultz (2005) mention, contain either open - end, or closed - end questions. Open - end questions are often answered after the subject has listened to a speech sample featuring the language or dialect towards which attitudes are being studied. The question might be something similar to in which contexts is it acceptable to use this language/dialect? Or describe the people who speak this language/dialect? The main idea in open - end questions is that subjects can use their own words when answering the questions instead of using ready-made scales or definitions invented by those who carry out the study. However, closed-ended questions are often used in questionnaires which, in turn, might consist of different statements concerning the language and its users, for example, It is important to study English in Singapore. Then, the subject has to choose from the ready-made answers to the one which indicates his/her attitude towards the matter. According to Baker (1992), a scale designed by Likert is used quite often in connection with this type of questions. The responses can simply be either Agree/Disagree or the measurement may be done more accurately with a five-point scale: Strongly Agree, Agree, Neither Agree nor Disagree, Disagree, Strongly Disagree.

\section{METHOD}

This action study was conducted with the cycle adopted from Ferrance (2000):

- Planning: the researchers chose a random of 20 students to get involved in doing the pre-test. The process 
of choosing these students was done by posting on the school's forum and those who volunteered to register first would be selected.

- Acting: the researcher planned to run The SFlook in twelve weeks and 20 students were categorized in 5 groups; each group consisted of 4 members with specific names like News, Learning, Opinion, Blog and Entertainment. The groups' duties were taking turn to produce 4 articles per week within two weeks for each. Before releasing the articles and posting on The SFlook, all 20 students had to participate in the training process lectured by a foreign lecturer.

- Observing: the researchers observed the students in the training section as well as giving support when necessary. Besides, they also co-operated with the foreigner to edit students' articles before publishing on The $S F$ Look.

- Reflecting: at the end of twelve weeks, the researchers asked students to do the post-test. Data were collected to see if students' writing skill was improved or not and to find out problems for further research.

\section{Participants}

The study was administered with 20 student members of The SFLook at a public university in Vietnam. These students are all Vietnamese speakers aged from eighteen to twenty two; however, their English language proficiency is different ranging from pre-intermediate to advance and they might be freshmen or senior students. As the members of the project, they have a strong passion for journalism and wish to improve their writing skill.

\section{Tests and Questionnaires}

The research recognized the appropriateness of the test method to compare students' writing skill before and after the intervention of SFLook for being a reliable method to check and evaluate knowledge (Halova and Kobilarov, 2010). Pretest and post-test had the same format using similar assessment items at the same level of difficulty. The pre-test was to set the student's baseline level of writing to access their article writing skill; and the post-test was to measure students' progress after 12 weeks of writing articles in different topics. In the pre-test, students were asked to write an article of 180 words on a sports event at SFL, TNU. And they are required to write an article on a volunteering program at SFL, TNU in the post-test.

In this study, questionnaire was given to the students after twelve weeks of writing and publishing various articles on different aspects on the official site. The questionnaire consisted of 15 questions which were divided into 4 main sections. Section 1 was to check the usefulness and of The SFLook. Section 2 covered the reasons why The SFLook was beneficial to students. Section 3 examined the specific aspects that students found their writing skill was improved. And section 4 asked students to express their achievements as well as obstacles while working with The SFLook with the limitation of 100 words only.

\section{The training section}

It is essential to have a training stage of article writing in the first lesson. According to Raimes (1983), it is a very useful tool as a starting point for training because it directs the students' attention to the elements which should be focused on. This idea is supported by Stanley (1992) when she states that "it is not fair to expect that students will be able to perform these demanding tasks without first having been offered organized practice with and discussion of the skills involved" (p.233). In addition to this, Berg (1999) reveals that the trained response group in his experimental research made significantly more meaning changes than the untrained group, and the quality of revisions made by the trained response group was significantly better than that of the untrained group, regardless of students' L2 language proficiency. Therefore, it can be concluded that the theory and the discussion of the results of this study strongly advocate the training to the students in the process of applying online newspaper to improve students' pieces of writing.

The first writings of these students were graded by experienced lecturers at School of Foreign Languages. The criteria for writing assessment were adapted from Nguyen (2012) including content, organization, vocabulary, grammar and mechanics. Then students enrolled in a class for developing writing skill with an American volunteer who majored in journalism. Lectures were divided into 4 main modules. For the first module, students were approached to basic concepts in the field of writing articles. Then the next module dealt with how to write an interesting and eye-catching title. After that, students were instructed to focus on the important contents included in an article. In the last module, students were suggested several techniques on how to write the articles beautifully.

\section{DATA ANALYSIS AND DISCUSSION}

\section{Answer to the First Question}

To What Extent Does The Student-Run Newspaper The Sflook Affect The Members' Writing Performance?

\section{Data collected from the first collection before the intervention of the SFLook}

According to the pre-test results, the students in the class were divided into 5 main groups: Excellent group (mark 9 - 10), good group (mark 8), fair to good group (mark 7), fair group (mark 5 to 6), and very poor group (mark 1 - 4).

As can be presented in Table 1, no students in the class obtained excellent grade. There were only $1(5 \%)$ students who got grade 8 . Similarly, students who got mark 7 were 8 (40\%). In contrast, those who got fair grades were higher than the previous groups with 9 (45\%). The remaining students who got very poor marks were the smallest in comparison with the other four groups, involving only $2(10 \%)$ students.

\section{Data collected from the first collection after the intervention of the SFLook}

According to the post-test results, the students in the class were divided into 5 main groups: Excellent group (mark 
9 - 10), good group (mark 8), fair to good group (mark 7), fair group (mark 5 to 6), and very poor group (mark $1-4$ ) (Table 2).

It is obvious that after 12 weeks of SFlook intervention, there was $1(5 \%)$ student getting excellent score which was really impressive. The number of those who got good grades was higher compared to the students in the pre - test with $5(25 \%)$. In contrast, the students who belonged to fair to good group were exactly the same as in the pre-test with $8(40 \%)$. There were $6(30 \%)$ students obtaining fair grades which were 3 students lower than those in the pre - test. More importantly, no students got very poor marks after joining in SFLook newspaper.

There is a considerable enhancement in students' writing performance, indicated by the fact that more students get good and excellent marks. The improvement is particularly presented at good level. It can be said that the project has positive impact on its members' writing. This result is similar to the findings of Alber (1999) when she concludes that employing class newspaper to develop students' writing performance is a big success.

\section{Answer to the Second Research Question: What are the Members' Attitudes Towards the Newspaper in Connection with their Writing?}

As can be seen from Figure 1, no students find that SFlook is not useful in improving writing. Meanwhile, a hefty $75 \%$ of students reveal that working with SFLook would be of great use in their writing performance. However, a quarter of students are not sure whether or not SFLook enhances their writing skill.

The data in figure 2 shows that half of students believe that being a member of The SFLook would help them improve the use of vocabulary. Meanwhile, only $25 \%$ of those reveal that their organization of writing was better. Similarly, the other one fourth sees the improvement in the content of their writings. Surprisingly, no students insist on the enhancement in the use of grammar, and mechanics (the

Table 1. Pre-test scores

\begin{tabular}{lcc}
\hline Sub-group & F & \% \\
\hline Excellent (9-10) & 0 & 0 \\
Good (8) & 1 & 5 \\
Fair to good (7) & 8 & 40 \\
Fair (5-6) & 9 & 45 \\
Very poor (1-4) & 2 & 10 \\
\hline
\end{tabular}

Table 2. Post-test scores

\begin{tabular}{lcc}
\hline Sub-group & F & \% \\
\hline Excellent (9-10) & 1 & 5 \\
Good (8) & 5 & 25 \\
Fair to good (7) & 8 & 40 \\
Fair (5-6) & 6 & 30 \\
Very poor (1-4) & 0 & 0 \\
\hline
\end{tabular}

use of punctuation, capitalization, contradiction and other conventions)

It is clear from Figure 3 that exactly $50 \%$ of students state that they learn more new words and make clear grammar rules when searching information and read authentic materials from different sources. Besides, the percentage of students thinking that they learn from friends'strong points and mistakes accounts for only $15 \%$. Additionally, the rate of students whose articles are read and they feel more comfortable and motivated are equal with $10 \%$. A minimal proportion $(5 \%)$ of students enjoys working with friends to discuss new writing ideas.

Looking at Figure 4, it is obvious that a half of students agree to brainstorm effectively, make effective outline, write a good introduction, revise their own writing and write under time constraint. In contrast, the small proportion of students thinks that they cannot write a good conclusion for an article essay or various patterns.

The data interpretation reveals some interesting findings about the students' attitudes towards the project. In general, they highly appreciate the effect of the newspaper. Most of the students believe that the SFLook has enabled them to develop their English, writing ideas and skills. Especially, the usefulness of the newspaper is likely to stem

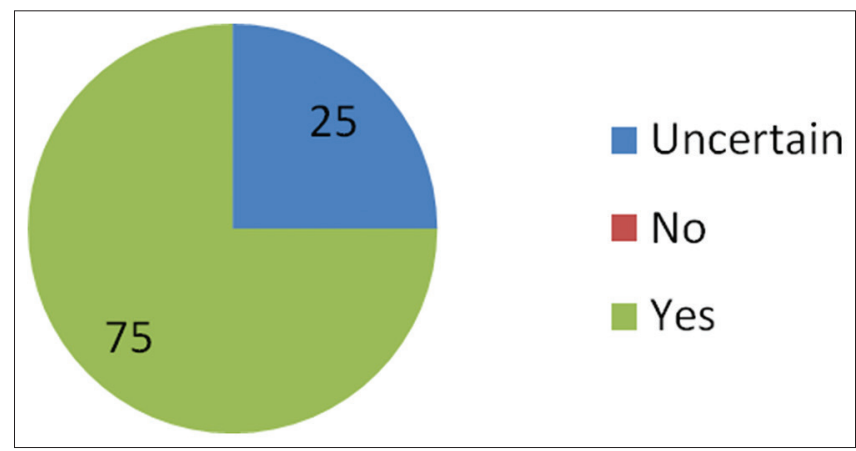

Figure 1. The SFLook is useful for my writing skill.

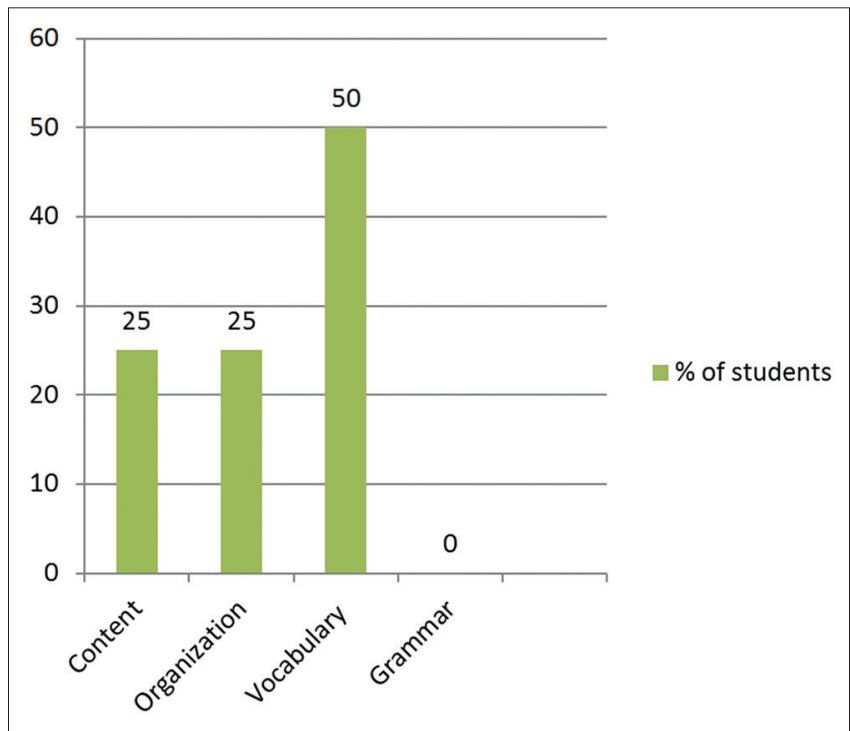

Figure 2. Working as a member of the SFLook helps me improve 


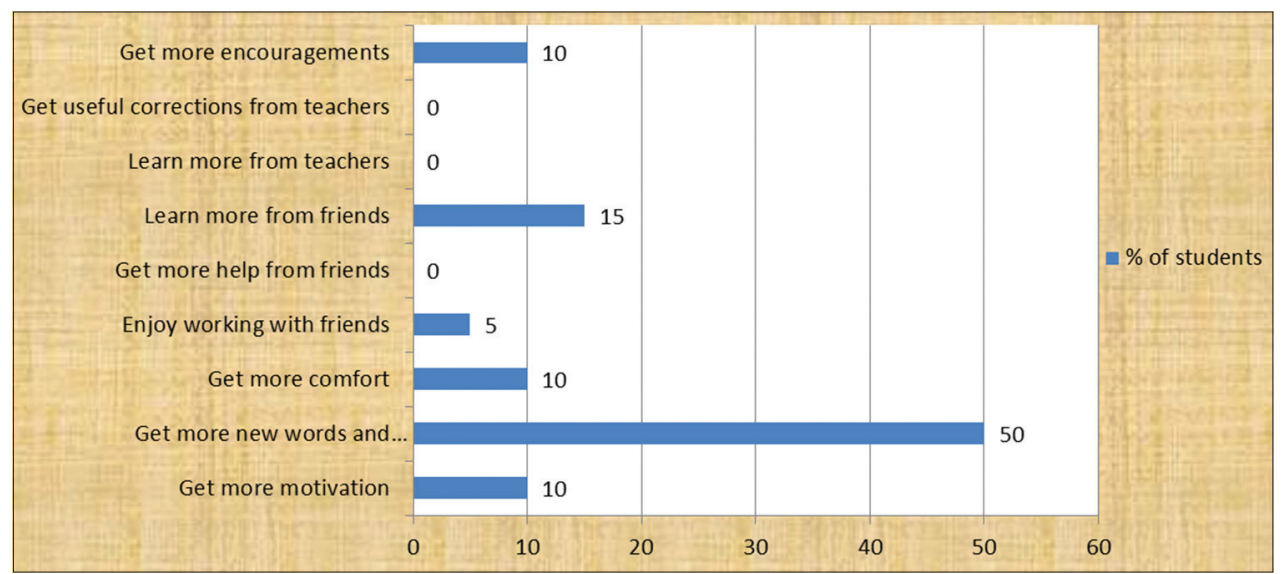

Figure 3. I think the SFLook is useful for my English writing because I

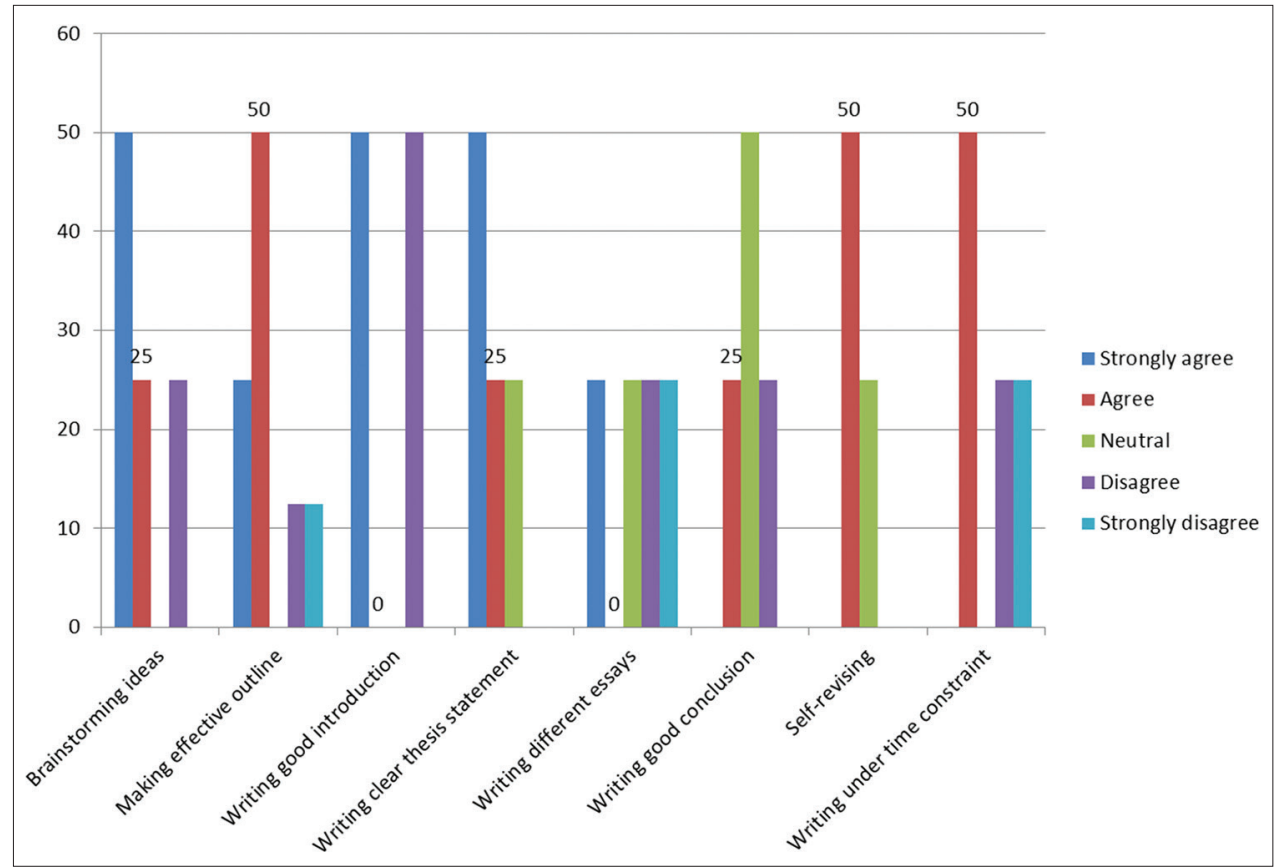

Figure 4. Self-assessment after taking part in SFLook

from browsing authentic materials. This can be justified by the fact that working with real newspapers is extremely important for a learner's connection with "real" English (Barbora, 2006). However, the students' motivations are still bound to external factors. It is suggested that more actions should be implemented for students to be intrinsically motivated.

\section{CONCLUSION}

Initially, it can be said that SFLook magazine has attracted a group of students with different language proficiency levels. After twelve weeks of being members of SFLook, students' writing skill seems to be better with the support of not only fellow friends but also the teachers. Nevertheless, a monthly writing contest was also held with prizes which were appeal to all students at School of Foreign Languages, Thai Nguyen University. This event has created motivation and equality for all students. Hence, the popularity of $S F$ -
Look was spreading in the community of School of Foreign languages.

However, SFLook has experienced several obstacles which need to be investigated in the future. First, student writers still find not confident enough to submit the articles. This can be easy to understand since students often need support from professional teachers. Second, this study was conducted with a small number of members; then the results could not be generalized to a larger population.

Obviously, this model is partly effective to students majoring in English. Other linguistic majors at SFL, TNU such as French Department, Russian Department, Chinese Department, Korean Department and Japanese Department might apply to students. Besides, the project hopes to obtain more budgets from sponsors to appeal to more students at the university. Last but not least, it is expected that lectures who are in charge of teaching writing skill would apply this model in the scope of their own classroom. In this case, they would require students to create an online class newspaper as a mini project. 


\section{REFERENCES}

Alber, S. R. (1999). “I Don't Like to Write, But I Love to Get Published": Using a Classroom Newspaper to Motivate Reluctant Writers. Reading \& Writing Quarterly, $15,335-360$.

Ajzen, I. (2005). Attitudes, personality, and behavior. Berkshire, England: Open University Press - McGraw-Hill Education.

Baker, C. (1992). Attitudes and Languages. British Library Cataloguing in Publication data: Multilinguial Matters Ltd.

Barbora, L. (2006). Using magazines and newspapers in ELT with interpersonal and intrapersonal types of students. Masaryk University: Department of English Language and Literature.

Berg, E. C. (1999). The effects of trained peer response on ESL students' revision types and writing quality. Journal of second language writing, 8(3), 215-241.

Dang, T. N. (2001). Exploring CALL Options for Teaching EFL in Vietnam. Theses, Disertations, and Other Capstone Projects. Paper 273.

Ellis, G. (1996). How culturally appropriate is the communicative approach? ELT Journal, 50(3), 213-218.

Ferrance, E. (2000). Action research. Northeast and islands regional educational laboratory at brown university: Brown University, Providence, RI.

Gipps, C. V. (1994). Beyond testing: Towards a theory of educational assessment. Routledge: London \& New York.

Halova, E., \& Kobilarov, R. (2010). Advantages and Disadvantages of the Test Method for Checking and Evaluating of the Knowledge, the Skills and the Habits of Students. Paper presented at the $7^{\text {th }}$ International Conference of the Balkan Physical Union.

Hapney, T. L \& Russo. C.J (2013). Student Newspapers at Public Colleges and Universities: Lessons from the United States. Marshall University: Educational Leadership Faculty Publications.

Hedge, T. (2005). Writing ( $2^{\text {nd }}$ edn). Oxford: Oxford University Press.

Kalaja, P. (1999). Beliefs about SLA: New Research Approaches. Springer: Netherlands.
Krajka, J. (2000). Some possibilities for using online newspaper in the ESL Classroom: The Internet TESL Journal, VI(4). Retrieved December $14^{\text {th }}, 2017$, from http://iteslj. org/Techniques/Krajka-OnlineNews.html

Le, V. (2000). Language and Vietnamese pedagogical contexts. In J. Shaw, D. Lubelska \& M. Noullet (Eds.), Proceedings of the Fourth International Conference on Language and Development (pp. 73-80). Bangkok: Asean Institute of Technology.

Mazdayasna, G., \& Tahririan, M. H. (2008). Developing a profile of the ESP needs of

Iranian students: The case of students of nursing and midwifery. Journal of English for Academic Purposes, 7, 277-289.

Nguyen, D. K., Phan, T. V., \& Ly, T. A. N. (2011). The Effectiveness of Activities for Teaching EFL writing in a Context of Vietnam: Journal of NELTA, 16(1-2), 82 - 96.

Nguyen, T. K. T. (2016). Critical Thinking's Effect on Vietnamese Students' Writing Attitude and Performance: Action Research. IORS Journal of Research \& Method in Education. 6(6), 38-43.

Nguyen, T.T.N (2012). The effects of Using Peer Correction on the students' writing performance at Hanoi Food Industry College. MA. Thesis, Hanoi University, Vietnam.

Nunan, D. (1989). Understanding language classrooms: A guide for teacher-initiated action: Prentice Hall Hemel Hempstead.

Oskamp, S. \& Schultz. P.W (2005). Attitudes and Opinions (Third edition). New York: Lawrence Erlbaum Associates, Inc \& Psychology Press.

Pham, H. (2000). Traditional versus Modern methods. Teacher's Edition, 2, 20-24.

Raimes, A. (1983). Techniques in Teaching Writing: New York: Oxford University Press.

Stanley, J. (1992). Coaching student writers to be effective peer evaluators. Journal of Second Language Writing, 1(3), 217-233.

Wenden, A. (1991). Learner strategies for learner autonomy: Planning and implementing learner training for language learners. ELT Journal, 48(3), 280 - 281. 